\title{
燃料電池型反応器の研究 II.
}

\section{三酸化モリブデン触媒膜の形態と反応特性との関係}

角田 達朗 ${ }^{*}$, 早川 孝, 今井 庸二, 亀山 哲也, 竹平 勝臣, 福田 健三

\section{A Study on a Fuel Cell Type Reactor II. \\ Relation between Morphology and Catalytic Behavior of $\mathrm{MoO}_{3}$ Films Deposited on a Solid Electrolyte}

\author{
Tatsuo TSUnOdA*, Takashi HAYAKAWA, Yoji IMAI, Tetsuya KameyAma, \\ Katsuomi TAKEHIRA and Kenzo FUKUDA
}

Received June 13, 1991 ; Accepted Novenber 5, 1991

\begin{abstract}
Catalytic activities of molybdenum trioxide films for partial oxidation of propene were studied in connection with their crystal morphologies. Catalytic activities were measured using an electrochemical cell system of propene, Mo03/AulYttria stabilized zirconialAg, $\mathrm{O}_{2}$. Porous films with preferential orientation of $(010)$ plane parallel to the pore channel and perpendicular to the substrate surface were obtained by the sputtering at 573K. They showed a higher activity and an acrylaldehyde selectivity than those of films with different textures and crystal morphologies obtained by lower temperature sputtering and the vacuum deposition. A relatively high step density was observed on the oriented (010) plane in the active catalyst films. The high activity of the catalyst films by the sputtering at $573 \mathrm{~K}$ is probably due to their high density of active sites for the partial oxidation of propene and also to their highly porous structure, which is favorable to the surface migration of oxygen to the reduced active sites.
\end{abstract}

\section{1 粕 蓉}

酸素イオン導電性を持つイットリア安定化ジルコニア （Y S Z と略す）等の固体電解質膜は，その雨面に外部 電圧を印加することで電気化学的に透過酸萃量を制御す る一種の酸素ポンプとしての機能をむっている1”。この 機能に着目して，接触酸化機能を有する金属を固体電解 質の電極膜に用いたセルや，場合によっては機能の问上 を図るためさらに触媒膜を電極膜上に形成したセルを作 製し，Y S Zを介して供給される酸卖により触媒膜表面 上で炭化水素などの接触酸化反応を行なわせ，部分酸化 反応における選択性を高めつつ，化学原料として有用な 生成物を得ようとする燃料電池型反応方式が注目されて (る $2 \cdot 3,4$ 。

これらの研究の多くは，電極膜または強媒膜の作慗に

化学技術研究所（干305つくば市東 1 - 1)

National Chemical Laboratory for Industry

(1-1 Higashi. Tsukuba, Ibaraki 305, Japan)

Key Words: $\mathrm{MOO}_{3}$ Thin Film, Zirconia,

Morphology, Catalyst
珼濁液の染布等の手法を用いているため，それらの膜は 多孔性であり，その膜形態についての検封もほとんど行 なわれていない。筆者らは，然料電池型反応方式の特徴 を明らかにするためには，触媒膜の形態や積層構造につ いても检討を加える必要があるとの立場から，形成され る膜の形热や結晶構造の再現性のよい真空蒸着法を触媒 膜の作製に用いた研究を進めてきた。第一報では，炭化 水卖，モリブデン酸ビスマス梁触媒膜／金|固体電解質 | 銀, 酸幸からなる燃料要池型反応器を構成し，プロピ レンの部分酸化反応活性が触媒の結昆型によって異なる ことを明らかにしだり。また，通常の流通法による触媒 反応ではによんど部分酸化活性を示さない三酸化モりブ デン $\left(\mathrm{MOO}_{3}\right)$ が, 本反灾方式により高い部分酸化活性を 示すことも報告しだの。しかしながう，触媒の特性に大 きな影響を与えると考えられる触媒膜の微細構造（モー フォロジーににつては充分な検討がなされているとは い光な。

本研究では，微細構造の異なるMOO3膜を作製し，それ らの膜の電気化学的接触反応特性をプロピレンの部分酸 化反応で評佋することにした。膜の作製法としてはす 
でに報告した真空蒸着法の他に，酸化性の雨囲気下で膜 形成が行なえるということ，およびより緻密な膜が得ら れる可能性があるという2 点に着目して, 反応性スパッ タリング法を新たに採用し，MO03膜の形態を中心に両法 の比較検討を行なった。

\section{2 実雅方法}

\section{1 三酸化モリプテン膜の作製}

抵抗加熱方式による真空蒸着法と D C プレーナーマグ ネトロン方式による反応性スパッタリング法の 2 種の成 膜法により，各々基板温度室温および $300^{\circ} \mathrm{C}$ でMoO3 膜を 作製した。基板としては直径 $32 \mathrm{~mm}$ ，厚さ $1 \mathrm{~mm} の 8 \mathrm{mo} 1 \%$ 小 ットリア安定化ジルコニア固体要解質 (Y S Z) の上に, アノードとしての金（Au）を $1 \mu \mathrm{m}$ 真空蒸着により作製 したものを用いた。この場合，Auは触媒膜と反応しない こと而酸化性の点加ら選定した。 $\mathrm{MOO}_{3}$ 膜の質量膜厚は $4 \mu \mathrm{m}$ としたが，その作製手順は以下に述べる通りであ る。

真空蒸着法による $\mathrm{MOO}$ 膜の作製は前報 ${ }^{51}$ にお付るすの

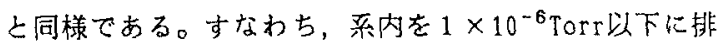
気し，基板温度を所定の值に調整した後，MoO粉末 99. 9\%) を蒸着原料として、よく脱がスを行なったアル ミナコートタングステンフィラメントで加熱して昇華さ せ基板上に蒸着した。蒸着量はフィラメントに装填され たMOO3粉末の量により，その全量を蒸発することで制御 した。

反吃性スパッタリング法によるMOO3膜の作製は以下の 通りである。ターゲットとしては直径 4 インチ厚さ $6 \mathrm{~mm}$, 純度 $99.9 \%$ のリブデン円板を用い，基板をターゲット に対向して設置されている加熱保温機構を持つ基板ホル ダーの中心に装着した。ターゲットと基板の距離は $7 \mathrm{~cm}$ である。スパッタリング空を $8.0 \times 10^{-7}$ Torrに真空排気 した後，酸素とナルゴン（O2 : $50 \%$ ，A r : $50 \%)$ を導 入し， $1.3 \times 10^{-2}$ Torrの压力に設定した。30分加ら1時 間のプレスパッタリングを行ない，安定した放電状況が 得られた後、シャッタ一を開いて蒸着を開始した。スパ ッタ笛力は300から350Wの間に設定した。蒸着速度は水 晶振動子式膜厚計により計測した。得られた蒸着速度は $0.8 \sim 1 \mu \mathrm{m} / \mathrm{hr}$ 程度でっった。作製された $\mathrm{HOO}_{2}$ 膜の微 細構造や結晶性は走查電子顕微鏡（SEM），および $\mathrm{X}$ 線回折法により評価した。

これらのMOO3膜は反応特性の評価に際し加熱されるた め, 構造変化を起こす可能性が高い。そのため，反応特 性評価中にお污構造变化を少なくする目的で，反応特 性評価に先立ちプロピレンの酸化反现環境を模した空気 中 $500^{\circ} \mathrm{C}$ の熱処理を作製された積層膜に施索こととした。 詳細は後述するが，作製直後のas-depositedの状態と空 気中 $500^{\circ} \mathrm{C}$ の熱処理を施した後の状態を SEMやX 線回
折で評洒した結果, 膜の種類によっては棒造変化を生じ たすのの，いずれの膜の場合も30分程度の熱処理により ほぼ変化がなくなることがわかった。そのため反応特性 評価汇は空気中 $500^{\circ} \mathrm{C}, 1 \mathrm{hr}$ の熱処理を施した積層膜を用 いることとした。

\section{2 フロビレンの接触酸化反店}

前項で述べたようにMO03／Au｜Y S Z を作製したのち 熱処理を施し，さらにY S Z 基板の亭面にカンードとし ての銀 $(\mathrm{Ag})$ 膜を真空蒸着法により作製し、 $\mathrm{MOO}_{3} / \mathrm{Au} I$ Y S Z |Agからなる四層構造の積層膜を構成した。これ を前報 ${ }^{5)}$ で述べた電気化学的酸化反応装置に組み込んで プロピレンの接触酸化反応を行なわせた。すなわち，反 応器は積層膜によって酸素供給室（カンード側）と反応 室（アノード側）に分割されており，アノード側にはプ ロピレンの希瀵ガスを，カンード側には酸素を流し，外 部からの電圧印加によりカソード側からアノード側触媒 に酸菜を供給してプロピレンの酸化反吣を行なわせた。 アノード側に供給する反纫ガスの組成は，5\%プロピレ ンー $5 \% \mathrm{~N}_{2}-90 \% \mathrm{H}$ e で，供給速度は $1400 \mathrm{~cm}^{3} / \mathrm{hr}$ であ る。カッード側への酸素供給速度は $600 \mathrm{~cm}^{3} / \mathrm{hr}$ とした。 反応温度は $475^{\circ} \mathrm{C}$ とし, 印加電死は反応に及ばす笔压の 効果を等しく吉るとの見地から1.0 Vの一定値とした。

酸素の積層膜通過速度はY S 2 の酸菜イオンの輸率を 1 と仮定して，皘層膜を反応中に透過する電流值加算 出した。また、アノード室出口のガスをガスクロマトグ ラフにより分析し，反応後の成分ガスの組成を決定した。 反応時間はほぼ一時間として, 各 $\mathrm{MOO}_{3}$ 膜の触媒特性を評 価した。本実験での反応はプロピレン転化率が低いため （1\%以下），プロピレンの消贅速度とアクロレインの 生成速度との比から算出する選択率で注誤差が大きくな る照念がある。本実験で検出された酸化生成物はアク口 レイン〈アクリルアルデヒド)，一酸化炭素, 二酸化炭 堔のみであったので, アクロレインの選択率はこれらの 生成速度から次式で算出することとした。

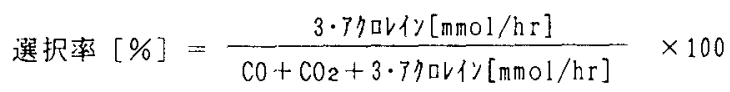

\section{3 桔果およひ考察}

\section{1 皘層膜の诚緗構造}

真空蒸着法により经板温度室温（R.T.）で作製された $\mathrm{MoO}_{3}$ 膜はかずかに黄绝を带びた透明な膜で，X線回折に よると非晶質状態でらり，SEM観察からは維密な膜で あったが，プロピレンの酸化反応環境を模した空気中 $500^{\circ} \mathrm{C}, 1 \mathrm{hr}$ 熱処理を施すことにより結晶化した。方の X 線回折パターン（Fig.1(b)）仕，標準回折パターン (Fig.1(a)） ${ }^{71}$ とよい対応を示した。熱処理後の膜の S E M 観察結果はFig.2(a)に示す通りで, 膜に微細な腺

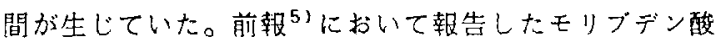


ビスマス系の触媒膜はSEMによる観察においても空陧 が認められなかったが，このMo03膜に関しては触媒膜中 にかなりの空㭞が存在することが分かった。しかしなが ら，SEM等による観察の範囲ではMOO3膜の欠落や娳離 は観察されなかった。

基板温度を上昇させると蒸着直後です青味を帯びた結 晶性の膜が形成される。Fig.1(c) は, 基板温度 $300^{\circ} \mathrm{C} て ゙$ 得られた膜のX線回折結果であるが，ちの回折パターン はMo03のそれ以外に，部分的に這元された sub-oxideか らの回折線に対応すると考元られるピーク（図中の*で 示す。JCPDS No.12-517：M002.80に相当）が認められた。

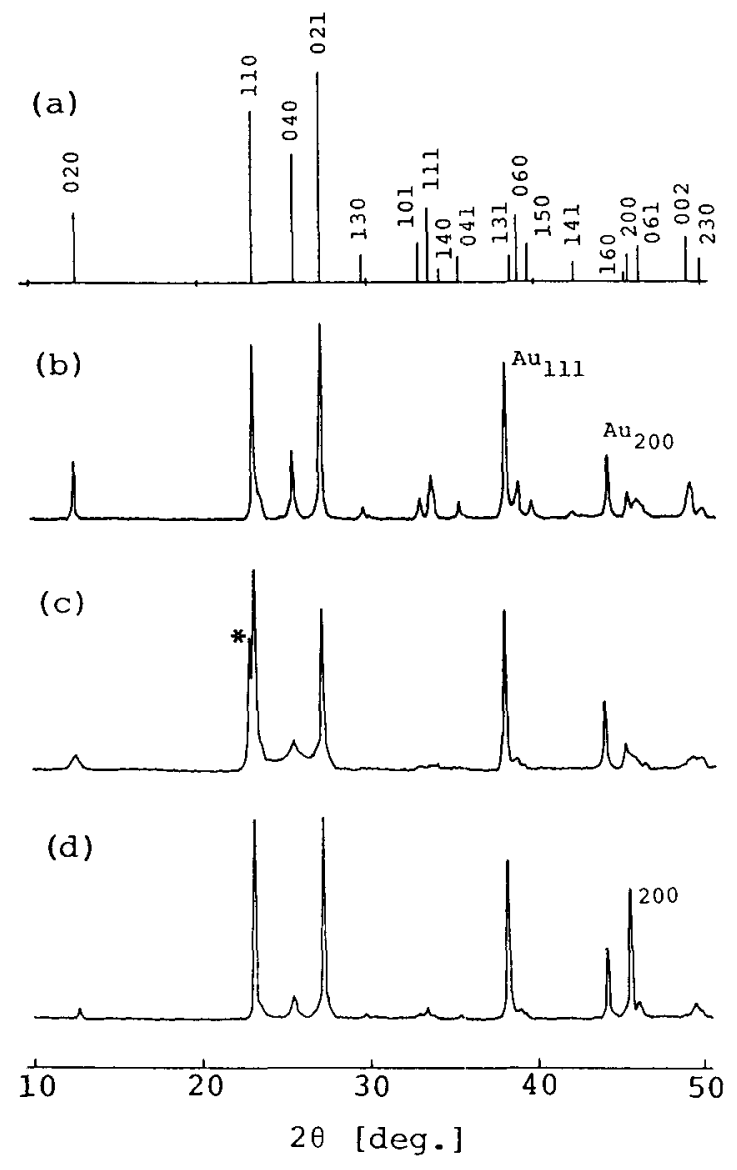

Fig. 1 X-ray diffraction patterns of $\mathrm{MoO}_{3}$ films prepared on Au/YSZ by vacuum deposition-annealing method;
(a): standard pattern (JCPDS).
(b): prepared at R. T. and annealed.
(c): as-deposited at $300^{\circ} \mathrm{C}$.
(d): prepared at $300^{\circ} \mathrm{C}$ and annealed.

この膜に対して空気中 $500^{\circ} \mathrm{C}, 1 \mathrm{hr}$ 熱処理を施した後の 膜のX線回折パターンは $\mathrm{MOO}_{3}$ 上同定できるものであった が，200反射が相対的に強くなっている一方，020

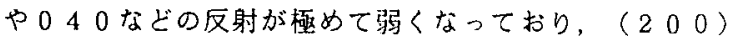
配向性が若干現われていると考えられる(Fig.1(d))。 この膜のSEM観察結果をFig.2(b)に示す。均整の取れ た板状結晶で構成された膜となっており，基板温度R. T. での真空蒸着膜よりも空陌多い棈造であった。MoO3は

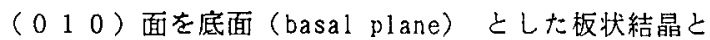
して成長しやすいことが知られている ${ }^{8)}$ 。この膜は，そ の（００１０）底面を基板面に㳔して垂直にする傾向を持 って板状結晶が成長した結果，（（２０００）配向を示した あのと考えられる。

基板温度R. T. で反応性スパッタリング法により作製し

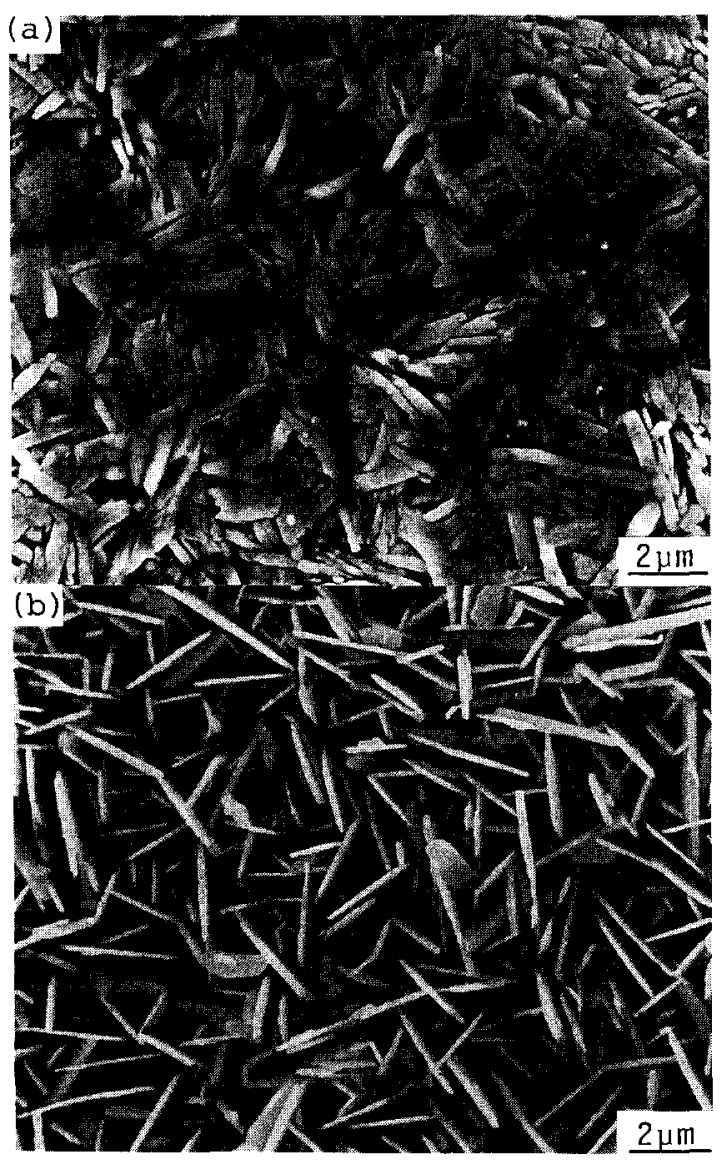

Fig. 2 SEM inages of $\mathrm{MoO}_{3}$ films prepared on Au/YSZ by vacuum deposition-annealing method; (a) : prepared at R.T. and annealed, (b): prepared at $300^{\circ} \mathrm{C}$ and annealed. 
た膜は，真空蒸着法による場合とほぼ同様にわずかに黄 色を帯びた透明な膜で，X線回折的には非晶質状態であ り，またSEMによる観综結果す真空蒸着法の場合とほ ぼ同様の表面構造であった。この膜に真空蒸着法と同様 の熱処理（空気中 $500^{\circ} \mathrm{C}, 1 \mathrm{hr}$ ）を施した膜は $\mathrm{MOO}_{3}$ 亡同定 される powder-1ike の回折パターンを示した（Fig. 3(b )）。SEM観察の結果はFig. 4(a) に示古通りであり， 膜の微細な割れなどの変化は真空蒸着法による場合( Fig. 2(a)) よりも少ない状態で結晶化が進行することが わかる。

一方，基板温度 $300^{\circ} \mathrm{C}$ で反心性スパッタリング法によ り作製した膜は，日〜淡灰色を呈し，Fig.3(c)に示す回 折パターンから作製直後ですほぼ完全に結晶化している ことがわかる。sub-oxide からの回折線に対応するピー クは認められず，真空蒸着の場合とは異なり部分還元の 生じていないMo03膜が得られることが判明した。その上, 200 反射のピークが極めて強くなっており，著しい優 先配向性が存在することがわかる。この膜を S E Mで観
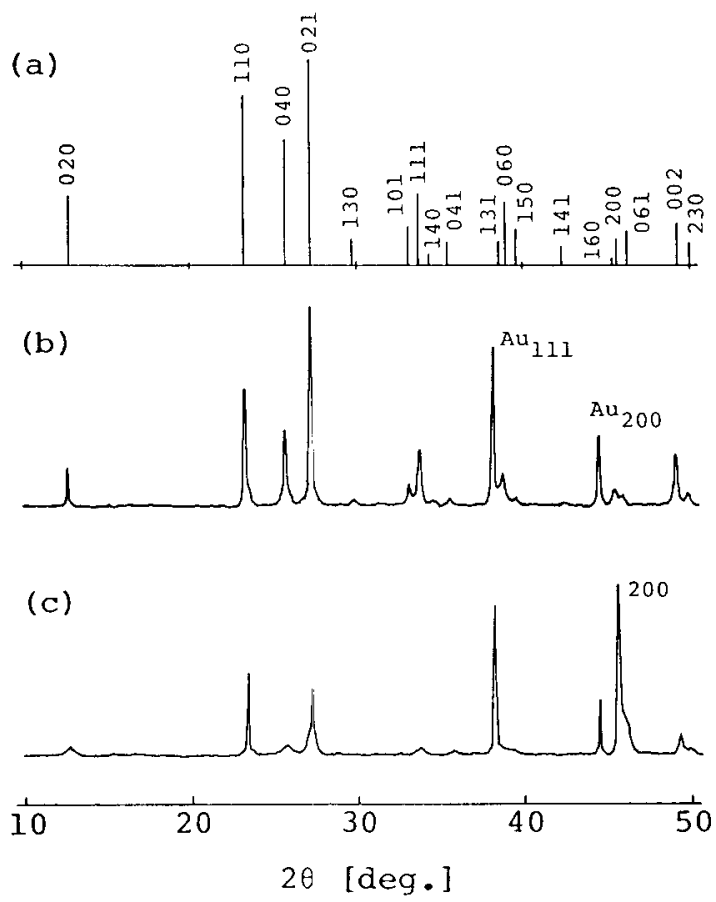

Fig. $3 \quad X$-ray diffraction patterns of $\mathrm{MOO}_{3}$ films prepared on Au/YSZ by reactive sputteringannealing method:
(a): standard pattern (JCPDS),
(b): prepared at R. T. and annealed,
(c) : prepared at $300^{\circ} \mathrm{C}$ and annealed.

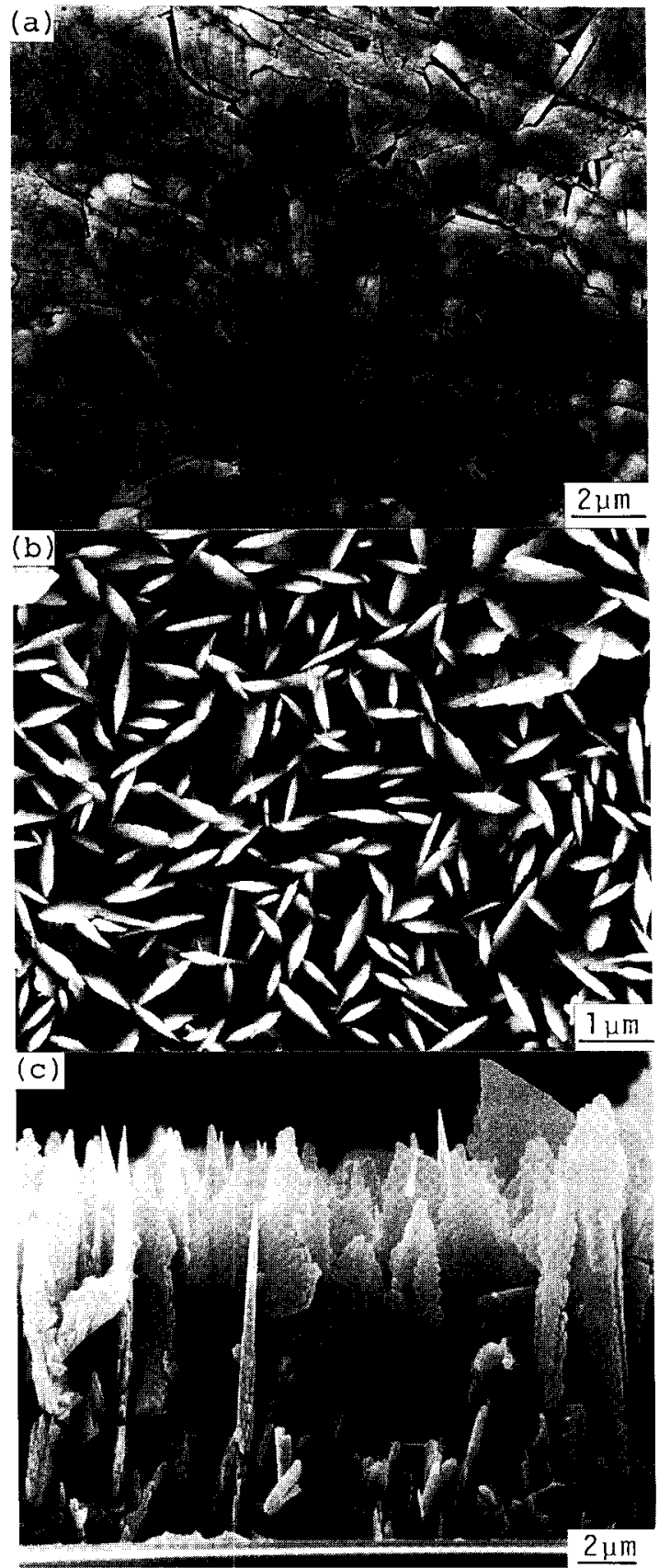

Fig. 4 SEM images of $\mathrm{MOO}_{3}$ filins prepared on Au/YSZ by reactive sputtering method:

(a): surface appearance of $\mathrm{MOO}_{3} \mathrm{film}$ prepared at R.T. and annealed,

(b): surface appearance of $\mathrm{MOO}_{3} \mathrm{film}$ prepared at $300^{\circ} \mathrm{C}$ and annealed,

(c) : cross section of $\mathrm{MoO}_{3} \mathrm{fi} / \mathrm{m}$ prepared at $300^{\circ} \mathrm{C}$ and annealed. 
察すると，Fig.4(b)に示すように板状の結晶により構成 された特徵的な微細構造を持っていることがわかる。こ の膜を断面から観察するとFig. 4(c)に示すように基板に 対して垂直な方向に板状の長手方向を揃えて結晶が成長 していることがわかる。X線回折に上る優先配向性とこ の微細構造との関係からこれらの板状結晶はMO03の [ $\left.\begin{array}{lll}1 & 0 & 0\end{array}\right]$ 方向を基板に垂直にして成長が起きているこ とがわかる。また，これらの板状結晶を基板から剝離し て透過電子顕微鏡による電子線回折を行なった結果, 板 状結晶の側面の広い面はMo03の( $\left.\begin{array}{lll}0 & 1 & 0\end{array}\right)$ 面に詨応し ていることがわかった。このような膜の構造は空気中 $500^{\circ} \mathrm{C}, 1 \mathrm{hr}$ の熱処理を施した後もほとんど变化しなか つた。

なお，膜の微細構造の特徵を表す一つの目安である緻 密さの度合をS E M 観察により評洒すると，基板温度 R.T. で反応性スパッタリング法により作製したMoO3膜 ( 以下 $\mathrm{S}_{\mathrm{RT}}$ と青く)が最す緻密で，次に基板温度R.T.での 真空蒸着法のもの（以下 VRTと書く）が続いた。基板温 度 $300^{\circ} \mathrm{C}$ で作製した膜は，真空蒸着法で作製した膜（以 下V300と書く)および反応性スパッタリング法により 作辋した膜（以下 S 300 と青く）のいずれる空㩐の大き な微細構造を持っており，外見的には似ていた。したが $\supset \tau$, 緻密さの度合は $S_{R T}>V_{R T}>V_{300} \sim S_{300}$ 順と なる。

\section{2 三酸化モリブデン膜の触媒特性}

基板温度をR.T.または $300^{\circ} \mathrm{C}$ として真空蒸着法および 反応性スパッタリング法により微細構造の異なる 4 種の Mo03膜が作製された。これらのMo03膜により構成された

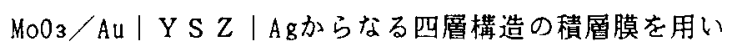
て，プロピレンの部分酸化反伈特性の評価を行なった。 比較のために, $\mathrm{MoO}_{3}$ 触媒膜のないAu | Y S Z | Ag三層構 造積層膜の評価る行なった。

反応中に積層膜を透過する電流值から算出した酸菜透 過速度をFig. 5 に示す。Fig. 5 より MoO3膜の作製方法に よって酸素透過速度に差があることがわかる。S 300 を 用いた積層膜の酸素過能は, 反応時間によらず一定值 を示した。これはその $\mathrm{MoO}_{3}$ 膜の微細構造が $500^{\circ} \mathrm{C}$ 程度の 熱処理では変化しないことを反映しているものと推察さ れる。また, $\mathrm{Au}|\mathrm{YS} Z| \mathrm{Ag}$ 三層積層膜よりも酸菜の透 過が起こり易くなっていることは興味梁い。このS 300 膜は，後述するようにプロピレンの部分酸化反心に对し て最も高い活性を示しておりこれらの結果については 後でまとめて考察する。

S 300を除く他の膜の酸系透過能は反応時間之共に若 干減少する傾向が認められた。これは反応時間と共に膜 の微細構造が变化していることなどが理由として考えら れるが，その詳細は搝討中である。しかしながら，その 酸素過能の順序が入れ替わることはなく，今回の実験
における反洔間の範囲では，反忘前に評価した膜の微 細構造の影響がその酸索透過能に充分及んでいるものと 考えられる。なお，前節で述べた膜の微細構造のS E M 観察によるみかけの緻密さによる順序 $\left(S_{R T}>V_{R T}>\right.$ $\mathrm{V}_{300}$ ～S $300 ）$ と酸菜の透過速度の順序とを比較する と，最む緻密なSRTが酸芰を通しにくいことは一致する が，他の順序は必ずしも一致しない。

反応後のガスの分析ではいずれのMoO3膜の場合も, 部 分酸化生成物アクロレイン(アクリルアルデヒド)，副 生した一酸化炭素および二酸化炭素, そ机に未反応のプ

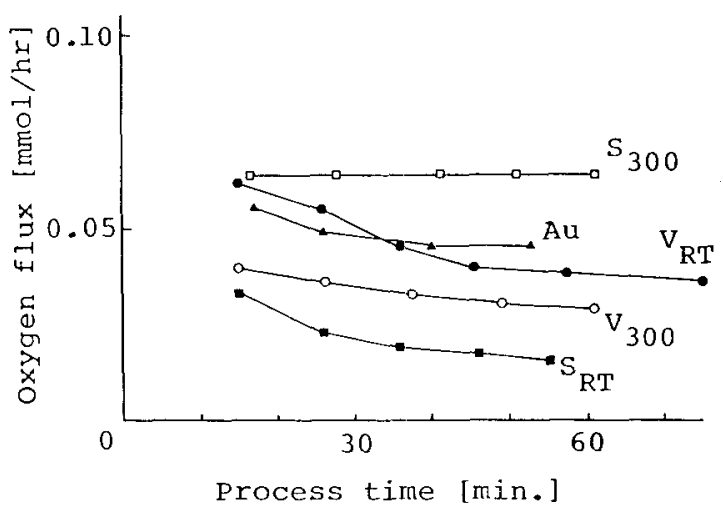

Fig. 5 Time dependence of oxygen flux transported through YSZ solid electrolyte.

$V$ : Vacuum deposition, S: Sputtering deposition, Subscript: Substrate temperature $\left({ }^{\circ} \mathrm{C}\right)$.

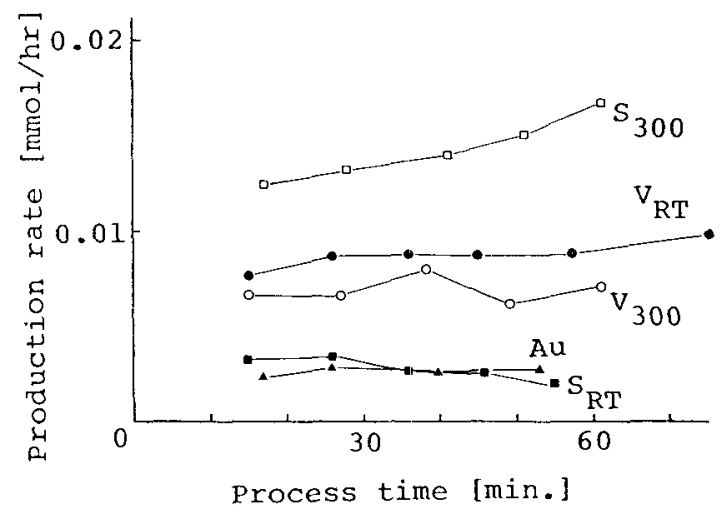

Fig. 6 Time dependence of acrylaldehyde production rate.

$V$ : Vacuum deposition, $S$ : Sputtering deposition, Subscript: Substrate temperature $\left({ }^{\circ} \mathrm{C}\right)$. 
ロピレンが検出されたのみであり，未反応の酸菜は検出 されなかった。各MO03膜によるアクロレインの生成速度 をFig. 6 に示す。 $\mathrm{S}_{3} 00 \mathrm{OMOO}_{3}$ 膜はV300，VRTDMO03 膜よりも高いアクロレイン生成速度を示した。 $\mathrm{SRT}$ の緻 密なMO03膜の場合には，A山のみの場合とはとんど变わら ないアクロレインの生成速度しか示さなかった。Mo03膜 がその膜中に適当な細孔径の空隙，すなわち，Y S Z を 透過してきた酸素種がM003の影響を受けることなく酸素 分子となって膜外に出てしまうようなことのない程度の

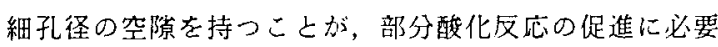
であるのであろう。アクロレインの生成速度は $\mathrm{S} 300>$ $\mathrm{VRT}_{\mathrm{R}}>\mathrm{V} 300>\mathrm{SRT}$ の順度であって，Fig. 5 に示した酸 索透過速度の順序と同じである。アクロレイン生成反纫 を促進する機能の高い触媒膜の場合には，その反応のた めに部分還元されたMO03 上の活性点が多く，この活性点 の再酸化によって酸芰が消費されるため，積層膜の酸菜 透過速度が大きくなるあのと考えられる。

Fig. 7 に各MO03膜によるアクロレインの選択率を示す。 S 300 を用いた積層膜は，他よりあ高いアクロレイン生 成反応の選択性を示している。アクロレインの選択率の 順序は，Fig. 5 に示した酸幸透過速度，Fig.6のアクロ レイン生成速度の順序と同じ〈S $\left.300>V_{R T}>V_{300}\right\rangle$ SRTの順序である。

酸化反応の場合一般的には，反応速度が大きくなるに したがい完全酸化も促進され，部分酸化反奻の選択率は 低下しがちである。本実験の結果はこ机とは逆に酸化反 応速度が大きい積層膜の場合ほど，選択率も大きいとい う特異な傾向を示している。この結果を触媒膜の構造と 関連づけて考察した。

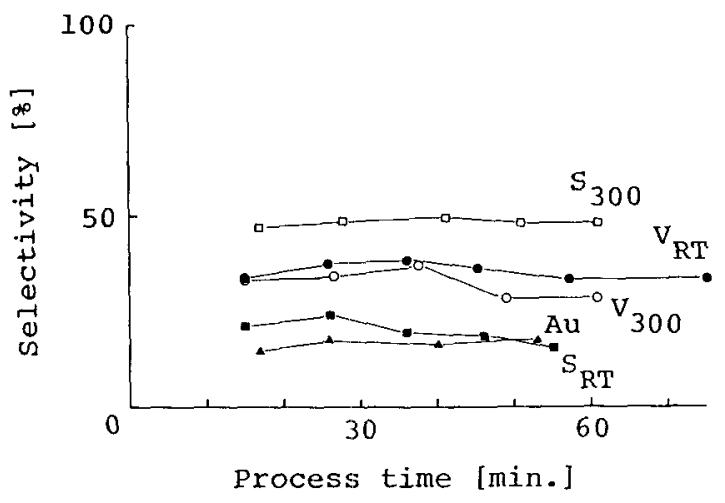

Fig. 7 Time dependence of selectivity of acrylaldehyde production.

$V$ : Vacuum deposition. S: Sputtering deposition, Subscript: Substrate temperature $\left({ }^{\circ} \mathrm{C}\right)$.
前報らにおいて用いたモりブデン酸ビスマス系触媒の 場合, アクロレイン生成に奇与する酸菜種はモリブデン 酸ビスマスの格子酸素であると考えられている9 。今回 検討を加えた $\mathrm{MOO}_{3}$ の場合もおをらくこれと同様に，M003 の格子酸菜によりプロピレンの部分酸化が進行している あのと考えられる。酸素イオン導電体として知られるモ リブデン酸ビスマスの場合，格子酸素が動き疁く，表面 加ら相当深い上ころにある格子酸素す酸化反心に奇与し ていることが知ら㣗ている101が，このモりブデン酸ビ スマスの場合に比較して て $\mathrm{MOO}_{3}$ の格子酸素は動きにくいも の上考えられる。しかしながら，Mo03膜にある程度の空 㩐が存在して表面積が大きいとき（S300，VRT，V300） には，プロピレンの酸化によりMO03上に形成される這元 サイトの数が多くなると共に，表面泳動や粒界拡散に上 る酸素の還元サイトへの供給量も多くなるので, 反応速 度が上がるものと考えら扎る。

通常の流通法による触媒反応の場合には，分子状酸素 の解離活性化がHoO3格子への酸荬の取り込みのために必 要であるが，部分還元されたMo03の再酸化は流通法では 起こりにくいことがわかっている11,12)。したがって， 流通法における定常状態でのMOO3はプロピレンによって 還元を受けると，以後再酸化を受けない限り触媒活性は 失われたままとなるため，流通法におけるM003枯酸化活 性が極めて低いもの上考えられる。本反応方式において は反纫室側のガス成分中に未反応の酸贲が咭められない ことから，この様な方式で電気化学的に供給された酸素 種はプロピレンにより僄元を受けたMo03上の還元サイト を容易に再酸化し，それが定常的に進行するため活性を 維持することができるものと考えられる。このような理 由により，元来固定床流通法では活性を維持することが できないMo03が，本反忘方式においては前報りにおいて 述べたように，モリブデン酸ビスマス膜に匹敵する部分 酸化活性を示したあのと考えられる。

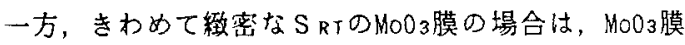
全体としての趇面積が小さく，MOO3上の還元サイトの数 が少なくなると共に酸䒺の補充す困難となり，Auのみの 場合と同じ程度のアクロレインの生成速度しか得られな いものと考えられる。

基板温度 $300^{\circ} \mathrm{C}$ で作製した膜（S300とV300）は，ど ちらの作製法によっても空隙が大きなものとなっており 程度の差はあるむのD同し配向性を持った多孔性の膜と なっているが，反吨特性には大きな差が認めら机た。こ の理由を明らかにするため，両法で作製した膜のより細 かな構造を S E M 考用いて再度比較することとした。

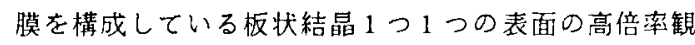
察像をFig.8(a).8(b) に示す。Fig.8(a)は反応性スパッ タリング法により作制した膜の板状結晶の表面構造を示 すが，かなりの密度でステップが存在していることがわ 
かる。一方, 真空蒸着法による板状結晶では, その表面 にステップは存在するもののその密度は低いことが分か る(Fig.8(b))。プロピレンの部分酸化反応には，M003

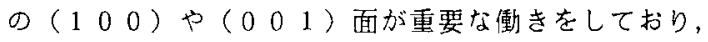
（０１０）面上では完全酸化が起こりやすいとの報告が ある13、14)。反性スパッタリング法で得られる板状結 晶の（（０１１０）面上に，基板面に対して平行に走る多く のステップが存在するということは，Fig.9にその模式

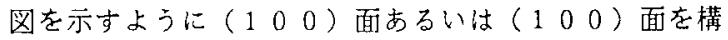

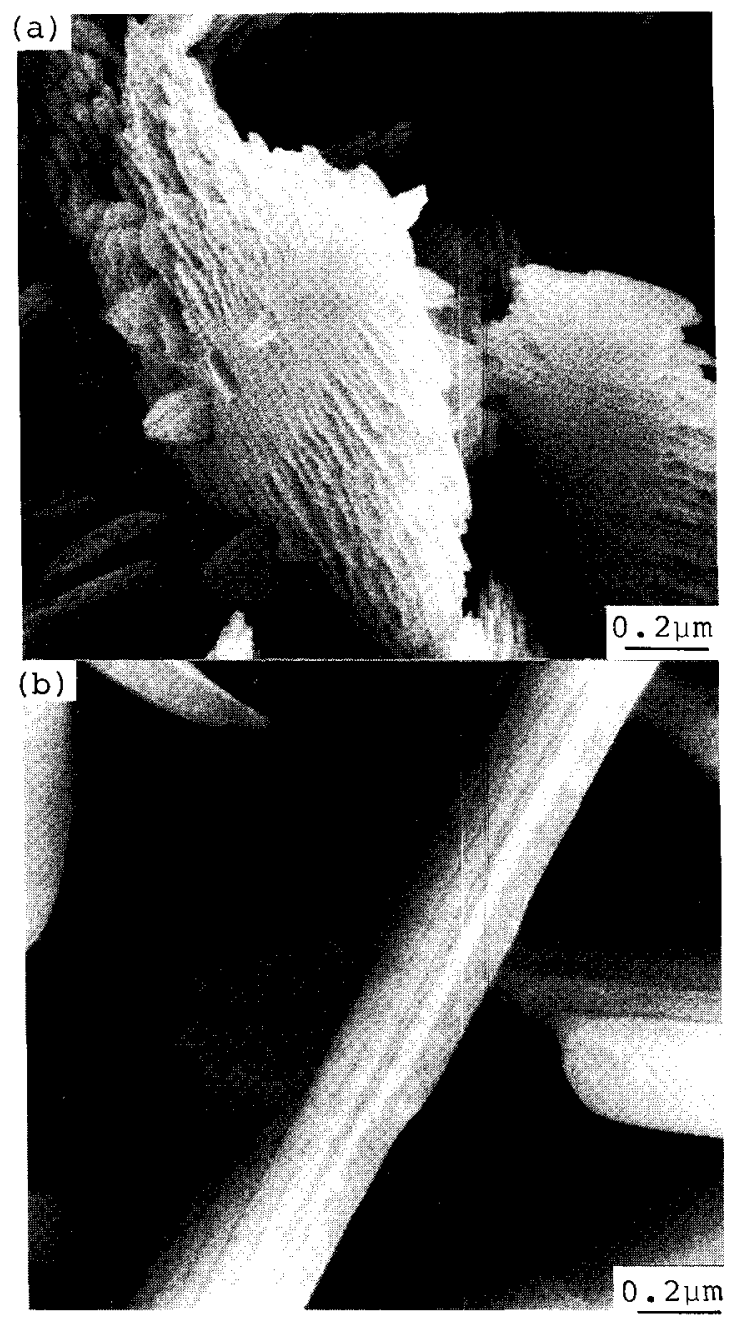

Fig. 8 High resolution SEM observation of $\mathrm{MOO}_{3}$ crystallites:

(a): prepared by reactive sputtering at $300^{\circ} \mathrm{C}$ and annealed $\left(S_{300}\right)$,

(b): prepared by vacuum deposition at $300^{\circ} \mathrm{C}$ and annealed $\left(V_{300}\right)$.

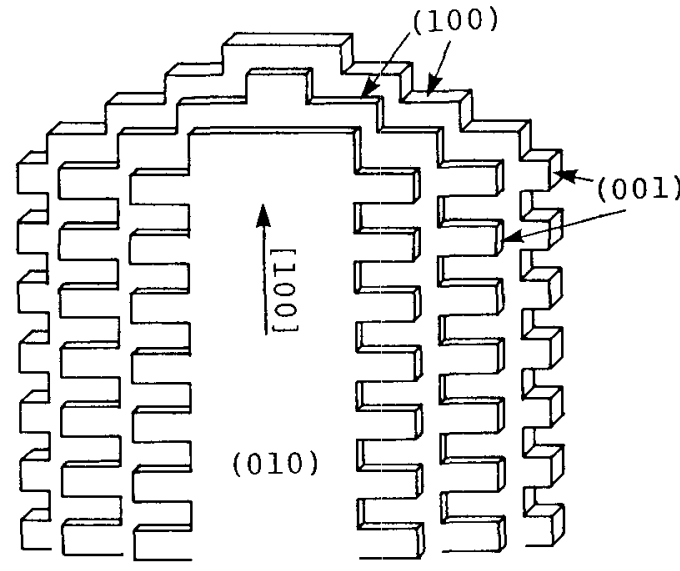

Fig. 9 Schematic diagram of the $\mathrm{MOO}_{3}$ crystallite prepared by reactive sputtering at $300^{\circ} \mathrm{C}$ and annealed.

成要素として持つ高次面の存在比率が大きくなっている ということであり，その配列の結果，反応性スパッ夕リ ング法により作製されたMo03膜は比較的高い選択率を示

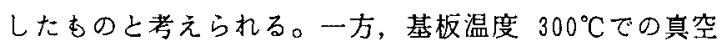
蒸着法によるMOO3膜は, 反応性スパッタリング法による ものとほぼ同様の配向性上多孔性を有しているにも関わ らず，そのMOO3結晶表面に存在するステップ等が少ない ため, 選択率の上昇が認められないあのと考えられる。

\section{4 楛 言}

真空蒸着法および反応性スパッタリング法で三酸化も リブデン膜を作製しその微細構造を決定するとともに， イットリア安定化ジルコニア固体電解質を介して電気化 学的に供給された酸贲による、プロピレンの部分酸化反 応に対する触媒特性を評洒した。基板温度 $300^{\circ} \mathrm{C}$ で反応 性スパッタリング法によって作製した膜（Ｓ300）は， 多孔性で且っ（０１１０）面が基板に垂直となるように板 状結晶として成長するが，その面上に数多くのステップ が存在していて, 部分酸化の反応速度, 選択性はともに 高い。一方，基板温度室温で反応性スパッタリング法に よって作製した膜（SRT）は維密で, 反忍速度も選択性

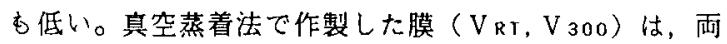
者の中間的な傾向を示した。これらの形態の異なるMo03 膜による部分酸化の反応速度や選択性は, $\mathrm{MOO}_{3}$ 膜の表面 に存在する活性点の数と，その活性点への酸素供給に影 響を与えるMOO3膜の微細構造に依存しているすのと推察 される。 


\section{文献}

1) E. C. Subbarao,' Solid Electrolytes and Their Applications', Plenum Press, New York, 1980.

2) M. Stoukides and C. G. Vayenas, J. Catal. 70, 137 (1981).

3) J. H. Michaels and C. G. Vayenas, J. Catal., 85, 477 (1984).

4) K. Otsuka, S. Yokoyama and A. Morikawa, Chem. Lett. , 1985, 319 (1985).

5）角田達朗, 早川孝, 高橋英郎, 折田秀夫, 竹平勝臣, 亀山哲也，福田健三，電気化学，56(4)，273（1988）。

6) T. Hayakawa, T. Tsuroda, H. Orita, T. Kameyama, H. Takahashi, K. Fukucla and K. Takehira. J. Chem. Soc., Chem. Commun., 1987, 780 (1987).
7) JCPDS Card No. 5-508.

8) L. A. Bursill, W. C. T. Goodman and N. Tate, Acta Cryst. A34, 296 (1974).

9) 秋本正道，触媒， $21 ， 371$ (1979).

10)諸岡良彦，表面，吕，421（1981）.

11）江頭誠，住江久欣，坂本光久，清山哲郎，工化誌， 73. 860 (1971).

12)早川孝，秋元正道，越後谷悦郎，石油誌， 25 , 343 (1982).

13) K. Brueckman, R. Grabowski, J. Haber, A. Mazurkiewicz, J. Slocynski, and T. Wiltowski. J. Catal., 104, 71 (1987).

14) J. C. Volta and J. M. Tatibouet, J.Catal., 93, 467 (1985). 